\title{
As entranhas do Brasil
}

\author{
Moacyr Godoy Moreira \\ Universidade de São Paulo
}

aramente política e literatura tiveram ligação mais íntima do que durante a Revolução de 1848”. Assim Dolf Oehler abre seu livro O velho mundo desce aos infernos (1999), no qual estuda relações íntimas entre os acontecimentos políticos de Paris em 1848 e o trabalho literário de Heine, Baudelaire e Flaubert. Oehler teve mais dois livros publicados no Brasil, Quadros parisienses (1997) e Terrenos vulcânicos (2004), abordando originais visões sobre este binômio por muitos renegado: literatura-história. Ou, ainda mais especificamente, um trinômio: história-literatura-sociedade.

O mais recente livro de Marçal Aquino, Eu receberia as piores notícias dos seus lindos lábios (Companhia das Letras, 2005), ponto alto de sua maturidade ficcional, permite-nos também uma leitura das entranhas do Brasil, em muitos sentidos, expostas ou ocultadas ao longo da obra com habilidade.

A escrita de Aquino permite leituras que se sobrepõem. Lembra aqueles cortes do solo vistos nos livros didáticos ou nos museus de ciências, através dos quais se percebe a composição das camadas: arenito por sobre a camada de cascalho, terra mais compacta que dá lugar a rochas e lá no fundo lençóis freáticos. Por vezes, veios inexplorados de petróleo.

Nesse romance, o primeiro do autor, já consagrado na realização do conto e da novela, Cauby, um fotógrafo paulista radicado no interior do Pará, numa área de garimpo e nervos à flor da pele, conta sua história e a de Lavínia, mulher de comportamento instável e de beleza sem igual, tesouro que as profundezas da terra expelem vez ou outra, como as pepitas de ouro pelas quais muitos morrem ou matam no lugarejo.

Cauby - sim, igual ao cantor, como não se cansa de responder à assertiva dos que o interceptam ao longo da vida - chega ao lugar para honrar a encomen- 
da de um grupo francês que financiara um livro de fotografias sobre as prostitutas do garimpo. A prosa entrecortada, a passagem imediata de um cenário presente para o da reminiscência, elemento que o autor toma emprestado do cinema, dá ao livro um ritmo fluente, como as dragas da mineradora que rumam rio abaixo, pautando conflitos entre a empresa e os garimpeiros.

O texto intercala o encontro de Cauby e Lavínia com o passado desta, muito mais que o dele, que é simplesmente esboçado. É Lavínia o centro dos acontecimentos, como é Marinês, mulher por quem seu Altino, velho morador da pensão em que Cauby está no momento em que o livro é contado, foi toda a vida apaixonado. O careca, como é chamado pelo fotógrafo, vai contando sua vida de desencontros enquanto este relembra sua passagem pela cidade, o florescer, o declínio e a queda de seu relacionamento com Lavínia.

Há um outro personagem chave na história: Ernani. Pastor da igreja Universal (ou algo do gênero), traz Lavínia de Vitória, a qual vivia na noite angariando fundos para sustentar seus vícios através da prostituição. Quando Cauby a conhece, já é casada com o pastor, figura importante do lugar. Há coadjuvantes de peso: Chang, o chinês dono de uma loja de material fotográfico, pedófilo e agiota; Viktor Laurence, sujeito de sexualidade indefinida, amante de livros e refinamentos incompatíveis com o lugar, editor do semanário da cidade e uma das poucas pessoas com quem Cauby consegue conversar.

Rumando para camadas mais profundas do romance, Lavínia pode ser vista como metáfora de uma nação repleta de potencialidades, porém cindida em seus desdobramentos por máculas morais e físicas sofridas na infância e na adolescência. Numa passagem do livro, o próprio texto convida-nos a um mergulho ao centro magmático da obra: "Porém, se você se aprofundar um pouco mais na ferida gangrenada que é a noite neste lugar, se subir as escadas rangentes de madeira e penetrar, sem medo ou nojo, na luz incerta dos submundos dos bordéis, surgirão outras versões".

Deixemos de lado o medo e o nojo (ou convivamos com tais sensações, inevitáveis num mundo real). O lugarejo em que Cauby se instala é também um micro-Brasil: uma empresa que domina a cidade, uma corja de políticos sem escrúpulos (apesar de o delegado Polozzi ser honesto e quase ingênuo), uma sociedade manipulada por fatos imaginados por Laurence em seu jornaleco e conduzidos, por outro lado, pela retórica do pastor Ernani. O povo, desorientado e irritadiço, capaz de linchar um suspeito de assassinato no mo- 
mento da emoção maior, porém incapaz de se organizar por condições sociais menos hediondas, é o reflexo desse nosso povo heróico e trabalhador, cujo brado só se ouve atrás dos trios elétricos e nos gritos de gol, que saqueia supermercados em noite de apagão, mas que não tem opinião formada sobre a extorsão e a derrama mantidas por meio de impostos e taxas sem fim.

A esquizofrenia de Lavínia, inicialmente colocada como capricho ou como crises depressivas eventuais, vai ao longo do romance sendo mais bem explicada, até o momento em que destrói, em fúria, objetos na casa de Cauby ou, dali a uns dias, aparece como recatada e arrependida esposa em pecado. A sucessão de incêndios que se segue ao assassinato do pastor e à descoberta de cinco garimpeiros assassinados a mando da mineradora é a reação de toda a cidade em ebulição. A convulsão e completo descontrole de Lavínia culminam com a convulsão febril de toda a cidade: incêndios, assassinatos, depredação, desordem.

Nas camadas ainda mais profundas, encontra-se, porém, um rio de águas claras, que se distancia da cidade sempre coberta de poeira. Um rio tortuoso, cheio de acidentes, porém resistente a tudo. $\mathrm{O}$ autor, em seu arremate, deixa ao leitor essa via possível que surge após graves e irremediáveis cicatrizes. $\mathrm{O}$ ponto final da história, com seqüelas físicas para Cauby e mentais ou emocionais para Lavínia, é positivo; são eles sobreviventes que, salvos, tentam recolher dos escombros o pouco que restou.

E, otimista, o autor deixa esboçada uma saída, algo que Carlos Drummond de Andrade chegou a afirmar certa vez ser o papel primordial do artista e da arte: uma possibilidade de elevação do próprio homem em relação a sua precariedade. Nessa história de fôlego e de arquitetura precisa, resta ao final um fio de luz. Uma sombra projetada do pouco que restou de dignidade. $\mathrm{O}$ suficiente para reinaugurar um país. Um território. 